\author{
Ewelina Sendek-Matysiak \\ dr inż. \\ Politechnika Świętokrzyska \\ Wydział Mechatroniki i Budowy Maszyn \\ esendek@tu.kielce.pl
}

DOI: 10.35117/A_ENG_20_03_02

\title{
The most important barriers to the development of electromobility in Poland
}

\begin{abstract}
In accordance with the Strategy for Responsible Development, by 2025, over 1 million electric cars powered solely from BEV batteries are to travel on Polish roads [24]. However, although such cars have a number of advantages such as lower maintenance costs, higher acceleration, lower maintenance requirements, lower noise levels than internal combustion cars, and above all no emissions at their place of use, BEV's share in the automotive market remains small and in 2018 year was only $0.1 \%$. Such a marginal number of currently used BEV electric cars in Poland, proves that the electric mobility market is still in the initial phase and its development limits various difficulties. This article discusses the most important barriers to the development of electromobility in Poland related to with the price of buying an electric car, the range of driving on a single charge, infrastructure dedicated to them. Solutions have also been proposed, which should certainly affect the decisions of users when choosing a vehicle with a given type of drive, and consequently the development of electromobility.
\end{abstract}

Keywords: Charging point; Electric vehicle BEV; Electromobility; External costs

\section{Introduction}

Transport is considered to be one of the most important factors stimulating economic activity as well as economic growth and development. It is thanks to him that the efficient and proper functioning of other branches of the national economy becomes possible. Expenditures on transport cause not only its development but also indirectly other parts of the economy [2], thus determining its competitiveness and efficiency.

Unfortunately, transport, apart from numerous benefits manifested in economic progress and development, also carries a very high risk in the form of external costs [4, 22], i.e. noise and vibration, surface and groundwater pollution, soil contamination, microclimate changes, land take for the construction of transport networks, accidents and, above all, air pollution (including $\mathrm{CO}_{2}$ and other gases causing the greenhouse effect) through exhaust gas emissions (tab.1).

In 2016, along with the energy sector, the transport was the main source of greenhouse gas emissions in the European Union and was responsible for $27 \%$ of their emissions [11], of which around three-quarters of emissions from this economic activity were caused by road transport, and passenger cars in particular.

Hence, the 21 st century brings many questions about the future of the automotive industry. The last three decades have seen rapid development in internal combustion engine technology. This was a consequence of the improvement of manufacturing techniques and the introduction of electronics to the automotive industry. While previously manufacturers focused on improving engine performance and efficiency, growing environmental awareness and new legal requirements have contributed to the focus on performance optimization and savings technology. As a result, modern cars powered by internal combustion engines are less harmful to the environment and reduce noise emissions, while maintaining excellent properties [14]. However, on a sectoral basis, the impact remains significant, not least due to 
the increasing number of vehicles on the road [39]. Fig. 1 shows the expected increase in the number of cars with internal combustion engines produced in the world, which is forecast to produce over 100 million units in 2020.

Tab. 1. Transport impact on the environment [38]

\begin{tabular}{|c|c|c|c|c|}
\hline $\begin{array}{c}\text { Environmen } \\
\text { tal impact }\end{array}$ & Air pollution & Water pollution & $\begin{array}{c}\text { Land and } \\
\text { forests }\end{array}$ & $\begin{array}{c}\text { Health and } \\
\text { safety }\end{array}$ \\
\hline 1 & 2 & 3 & 4 & 5 \\
\hline constant & & & $\begin{array}{c}\text { land use, } \\
\text { landscape } \\
\text { destruction, } \\
\text { population } \\
\text { displacement }\end{array}$ & \\
\hline $\begin{array}{l}\text { during } \\
\text { operation }\end{array}$ & $\begin{array}{c}\text { emissions of CO2 } \\
\text { and other } \\
\text { greenhouse gases } \\
\text { (including HC2) }\end{array}$ & spread of pollution & $\begin{array}{c}\text { acid rain, } \\
\text { harmful } \\
\text { influence }\end{array}$ & $\begin{array}{c}\text { accidents, noise, } \\
\text { vibration }\end{array}$ \\
\hline $\begin{array}{l}\text { risk during } \\
\text { reloading }\end{array}$ & $\begin{array}{l}\text { spread of } \\
\text { hazardous } \\
\text { substances }\end{array}$ & $\begin{array}{l}\text { spread of } \\
\text { hazardous } \\
\text { substances }\end{array}$ & $\begin{array}{c}\text { spread of } \\
\text { hazardous } \\
\text { substances, risk } \\
\text { of fire }\end{array}$ & $\begin{array}{c}\text { toxic leaks, risk } \\
\text { of fire and } \\
\text { explosion }\end{array}$ \\
\hline & congestion & $\begin{array}{r}\text { Comp } \\
\text { operation, } \\
\text { to wasted }\end{array}$ & $\begin{array}{l}\text { ared to the effect } \\
\text { congestion has a } \\
\text { time and reduced }\end{array}$ & $\begin{array}{l}\text { luring normal } \\
\text { reater impact due } \\
\text { energy efficiency }\end{array}$ \\
\hline \multicolumn{5}{|c|}{ Impact rank according to environmental elements and modes of transport } \\
\hline roads & $* * *$ & $*$ & $* * *$ & $* * *$ \\
\hline rail & $* \mathrm{~b}$ & & $* *$ & $*$ \\
\hline waterways & & $* *$ & $*$ & \\
\hline $\begin{array}{l}\text { maritime } \\
\text { transport }\end{array}$ & $*$ & $* *_{\mathrm{c}}$ & $*$ & \\
\hline air transport & $*$ & & $*$ & $*$ \\
\hline
\end{tabular}




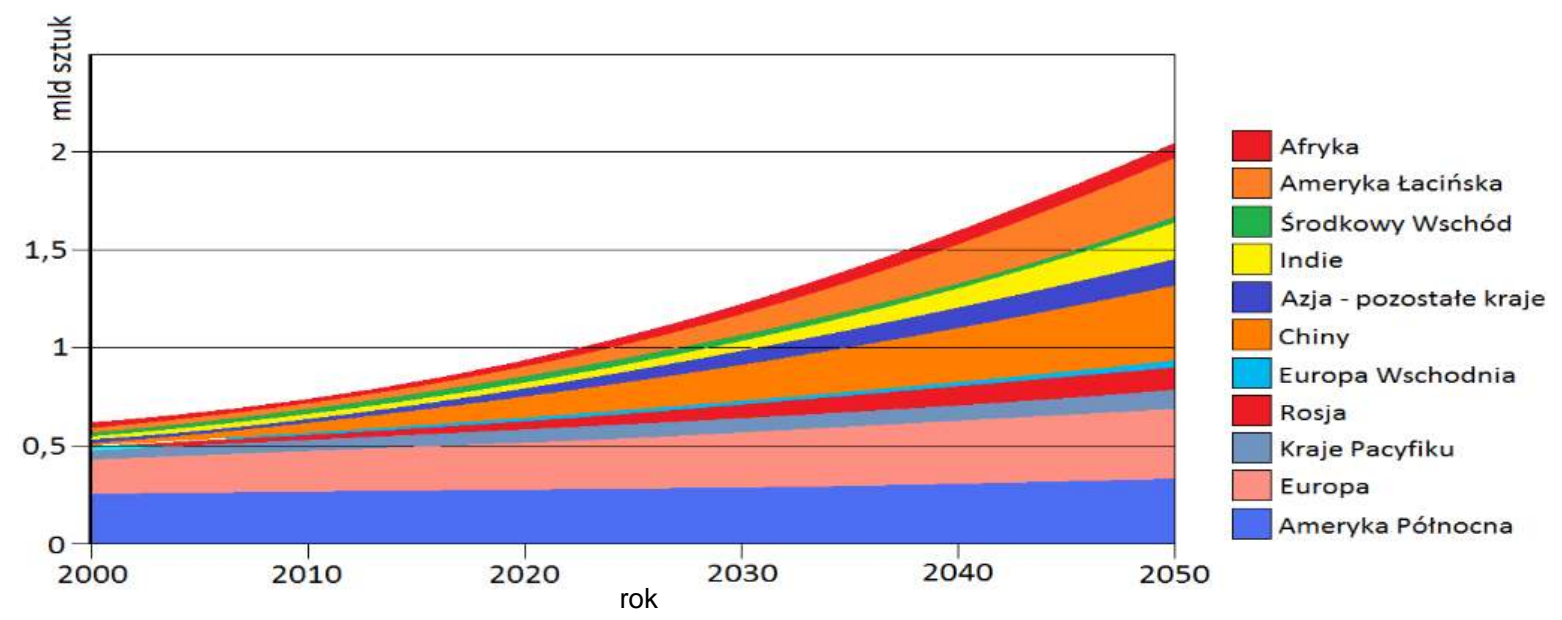

1. Projected number of cars produced in the world in 2050 [11]

Therefore, the continuous increase in the demand for transport requires taking further steps to limit its negative effects $[12,36]$.

In connection with the above, but also due to the rising oil prices, car manufacturers are looking for other propulsion sources than the internal combustion engine. It should not be forgotten that oil resources - the raw material for the production of fuels used in cars - are limited, and most of the deposits are found in politically unstable areas [28, 29]. Both of these factors carry the risk of an automotive. Vehicle manufacturers are aware that the one that meets the needs of an alternative solution, cheaper and no less reliable than an internal combustion vehicle, may become a leader in the automotive industry. At present, apart from the dangers of the crude oil market, the ecological brand image is also very important and has a direct impact on sales results. It is related to the increasing social awareness and effective lobbying of environmental organizations. An alternative to internal combustion engines seems to be cars with a BEV electric motor.

\section{Share of electric cars in the automotive market in Poland}

By analyzing the global statistics of the growth rate of electric cars (Fig. 2) and being aware of the EU requirements regarding, inter alia, improvement of air quality (e.g. reduction of GHG (Greenhouse Gas) from transport by $60 \%$ to 2050 vs. 1990 [23]), Poland will also face the era of electricity in transport. The Ministry of Energy assumes that one million electric cars will be registered in the country by 2025 (Table 2).

Tab. 2. Planned growth path in the number of electric cars in Poland, 2018-25 [30]

\begin{tabular}{ccc}
\hline Year & New BEV registrations & Number of electric cars \\
\hline $\mathbf{1}$ & $\mathbf{2}$ & $\mathbf{3}$ \\
\hline 2018 & 7872 & 13576 \\
\hline 2019 & 18734 & 32310 \\
\hline 2020 & 44588 & 76898 \\
\hline 2021 & 106119 & 183017 \\
\hline 2022 & 183017 & 366034 \\
\hline 2023 & 183017 & 549051 \\
\hline 2024 & 274525 & 823576 \\
\hline 2025 & 205894 & 1029470
\end{tabular}


However, despite the fact that the number of newly registered electric cars is constantly growing year by year (Fig. 3) (medium-term rate of change $\bar{T}_{G}=36 \%$ ), the share of BEV electric cars in Poland is still only $0.1 \%$ in the automotive market. However, in the European Union, it is at the level of $0.8 \%$ (Fig.4).

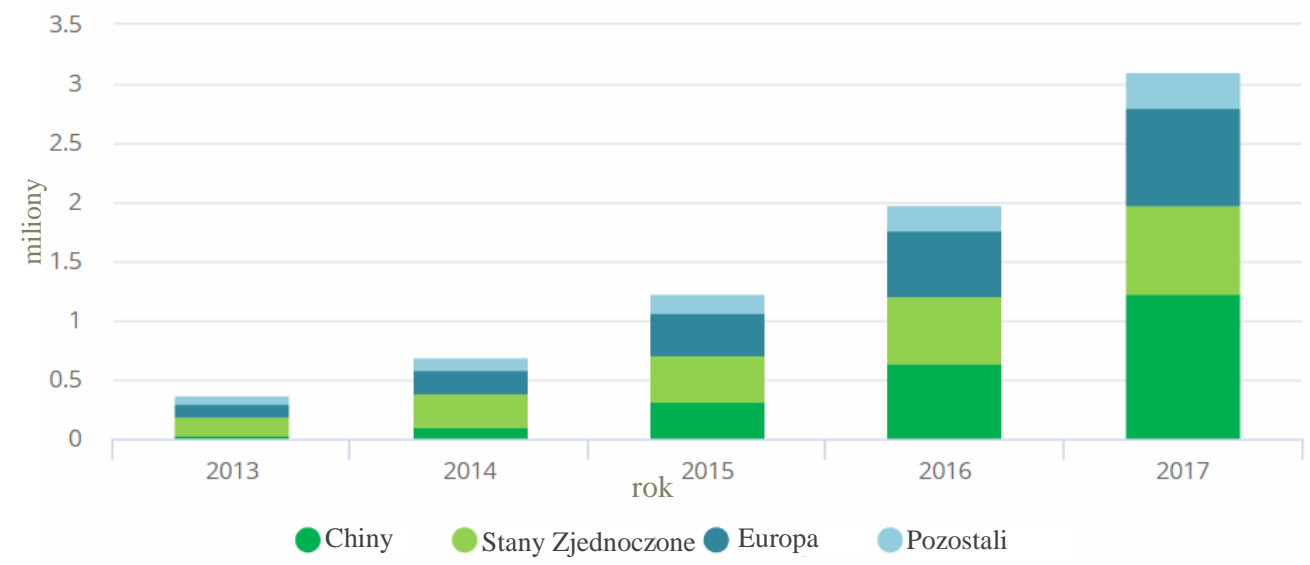

2. Number of cars with an electric motor in the world [13]

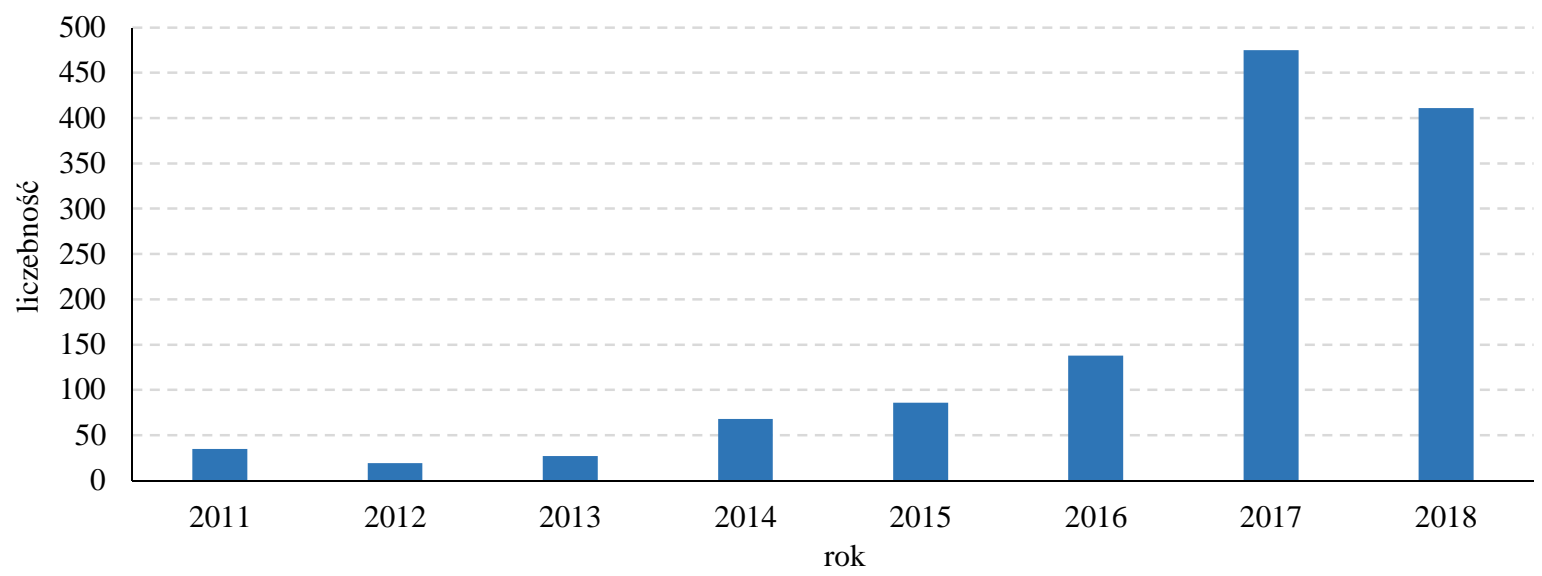

3. Number of new registrations of BEV electric cars in Poland, 2011-18 (own study based on [9])

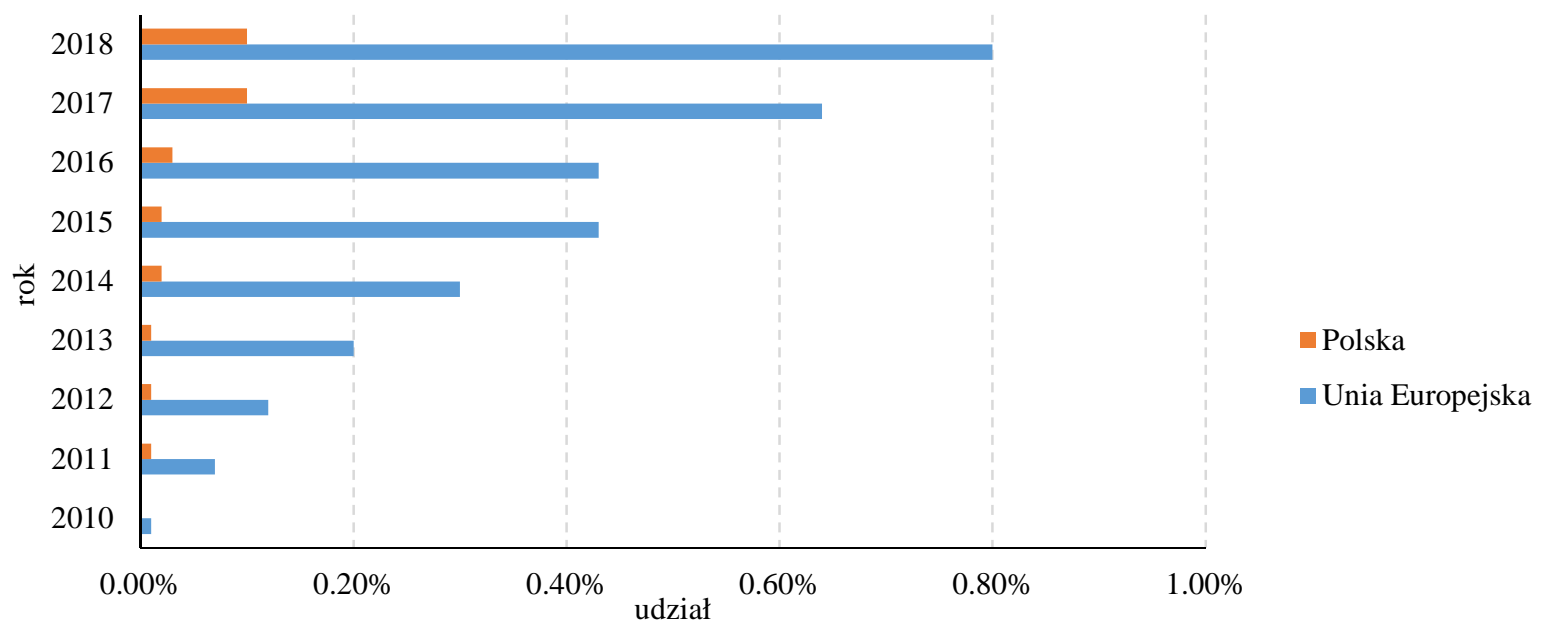

4. BEV passenger car market share in the European Union and Poland, 2010-18 (own study based on [9]) 


\section{Barriers to the e-mobility development}

The marginal number of currently used BEV electric cars in Poland proves that the electric mobility market is still in the initial phase. Its development is limited, among others, by such barriers as:

- EV purchase costs, largely determined by the cost of the battery (the weight of the battery is also a barrier),

- poorly developed charging infrastructure,

- short travel range on a single charge (battery capacity),

- long battery charging time.

\section{Purchase cost and limited choice}

Today, having an electric car - although it has many advantages - is still quite burdensome for the user. The first difficulty when buying such a vehicle is a limited choice and then the price. In 2018 (as of 06.2018), consumers could choose from only fifty-two BEV models (in Poland - 15 models [8]) with over four hundred ICE (Internal Combustion Engine) models. Often, BEV models cannot be viewed in the showroom, and after purchase, you have to take into account longer waiting times for collection. Moreover, not all dealers sell such cars. For example, a Volkswagen with an electric drive can be bought in Poland and then serviced only in 4 out of 85 dealerships of this concern [19].

Almost all consumer studies have shown that one of the main obstacles to the implementation of e-mobility is the higher price of battery electric cars compared to similar models with conventional combustion engines [3, 6, 37, 41].

This is also confirmed by research carried out by Kantar Public, which shows that the most important factor when buying a car is its price. Figure $\mathbf{5}$ presents the results concerning the answer to the question What criteria are the most important for you when purchasing a car? (more than one answer possible) [21].

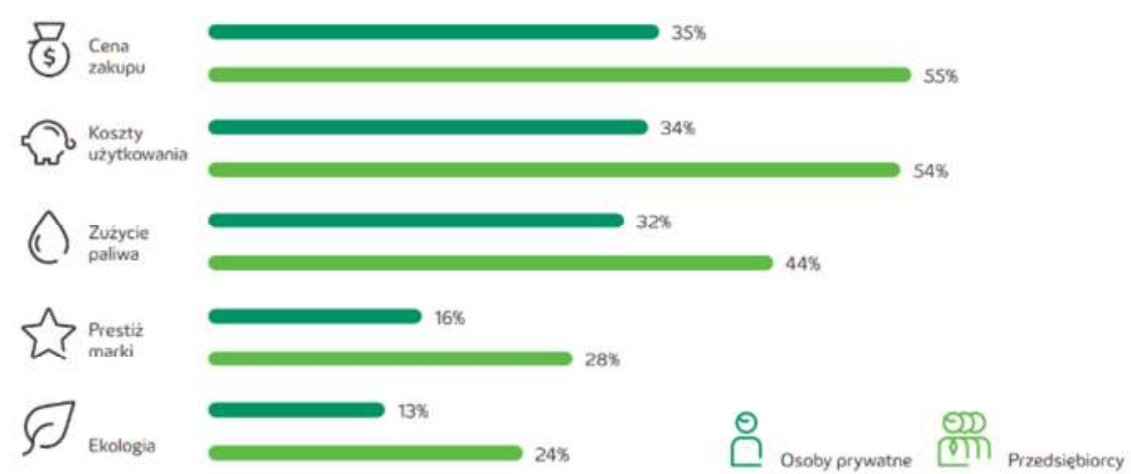

5. The most important criteria taken into account by the buyer of a car in Poland [21]

Currently, in Poland, for a car powered only by a battery, you have to pay at least PLN 100,000 PLN (exception: two-person Renault Twizy - from 53200 PLN) (Fig. 7). Comparing their price with their counterparts with internal combustion engines, it is at least twice as high (Table 3). At this point, it should be added that for many years, among Polish car buyers, vehicles imported from countries located west of Poland's borders have been very popular. They are often over 20 years old, according to data [11], in 2017 they accounted for $33.7 \%$ of the automotive market. In 2018, more than half of new car registrations were registrations of cars over 10 years old (Fig. 6). Such a large interest in such cars is undoubtedly due to the purchase price, which is the maximum amount of around 50,000 PLN. 
Tab. 3. The price of selected, new passenger cars with various engines in Poland (PLN) [24]

\begin{tabular}{lcccccc}
\hline BRAND & $\begin{array}{c}\text { EV } \\
\text { MODEL }\end{array}$ & PRICE & $\begin{array}{c}\text { Z ZS } \\
\text { MODEL }\end{array}$ & PRICE & $\begin{array}{c}\text { Z ZI } \\
\text { MODEL }\end{array}$ & PRICE \\
\hline $\mathbf{1}$ & $\mathbf{2}$ & $\mathbf{3}$ & $\mathbf{4}$ & $\mathbf{5}$ & $\mathbf{6}$ & $\mathbf{7}$ \\
\hline \multirow{2}{*}{ Nissan } & Leaf & $\begin{array}{c}128000- \\
165000\end{array}$ & Juke & $\begin{array}{c}72000- \\
84000\end{array}$ & Juke & $\begin{array}{c}72000- \\
89000\end{array}$ \\
\hline \multirow{2}{*}{ Renault } & \multirow{2}{*}{ Zoe } & $\begin{array}{c}121900- \\
143000\end{array}$ & Clio & $\begin{array}{c}56500-63 \\
000\end{array}$ & Twingo & $\begin{array}{c}46000- \\
62000\end{array}$ \\
\hline \multirow{2}{*}{ Volkswagen } & \multirow{2}{*}{ e-golf } & 162890 & golf & $\begin{array}{c}86000- \\
118000\end{array}$ & golf & $\begin{array}{c}80000- \\
94000\end{array}$ \\
\hline Volkswagen & e-Up! & 115190 & - & - & Up! & 40000 \\
\hline
\end{tabular}

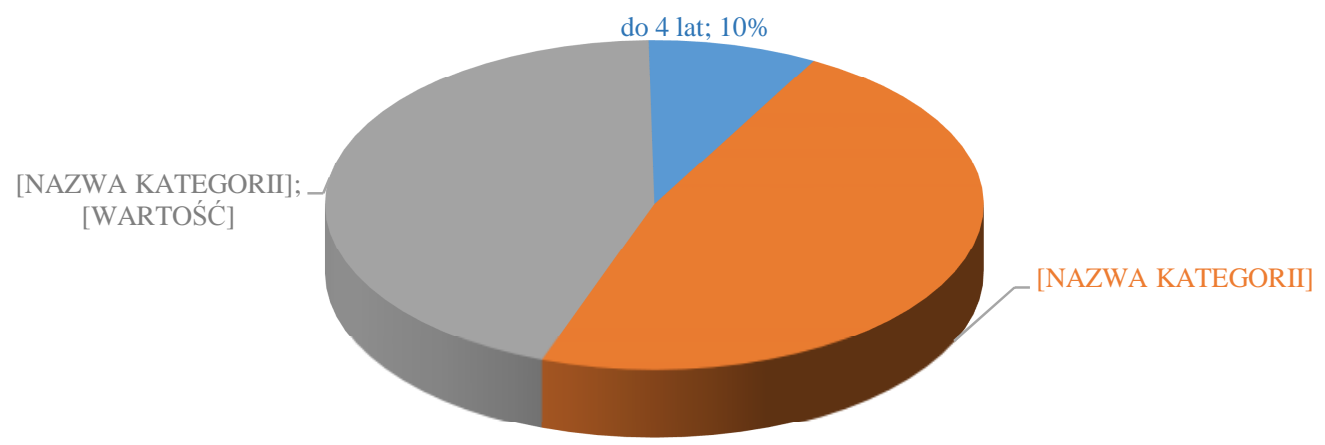

6. First registrations of used passenger cars, January-November 2018 - age structure (own study based on [34])

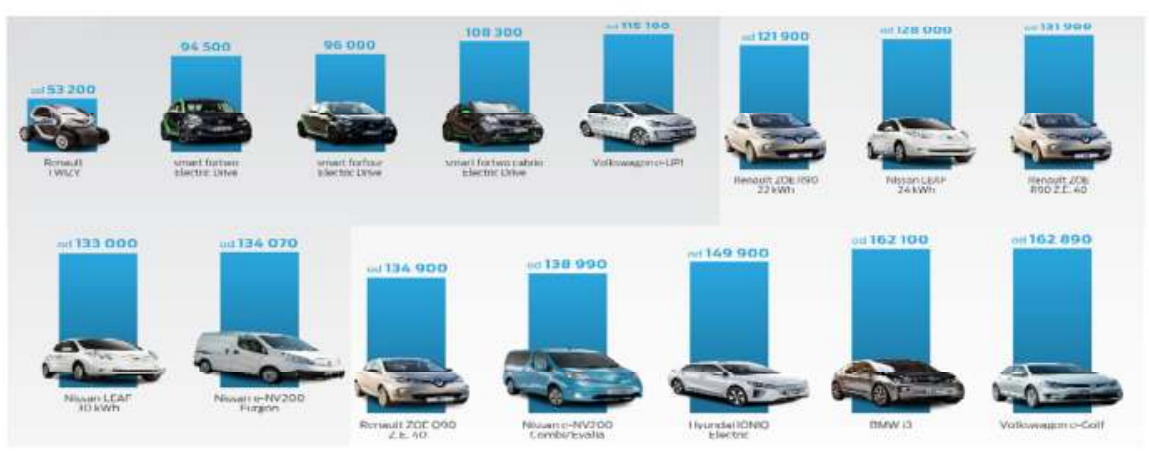

7. Electric car prices (PLN) [39]

Figure 7 shows the prices (PLN) of new EVs, and for selected ones, Table 3 compared with the prices of conventionally powered cars of similar power and equipment.

\section{Charging infrastructure}

The problems related to the dissemination of battery-operated cars should be considered not only in terms of finance but also their efficiency, long charging time and infrastructure barriers.

The infrastructure in this market relates mainly to the network of charging stations on which the mobility of electric vehicles depends and appears to be a key barrier to market diffusion, as well as a major source of concern for consumers to change their preferences. According to research conducted among Polish drivers, the lack of generally accessible 
charging infrastructure is currently one of the main factors discouraging them from purchasing an electric car [6,21,32].

In 2018, the number of public charging points in Poland was 631 (Fig. 8), which means that there were 6 PEV (Plug-in Electric Vehicle) cars for each of them (Fig. 9). Directive 2014/94 / EU "Clean Energy for Transport" of the European Parliament and of the Council recommends that the Member States have one publicly accessible charging point for every 10 registered electric and plug-in hybrid cars [5]. It follows that the number of such chargers in Poland is currently sufficient.

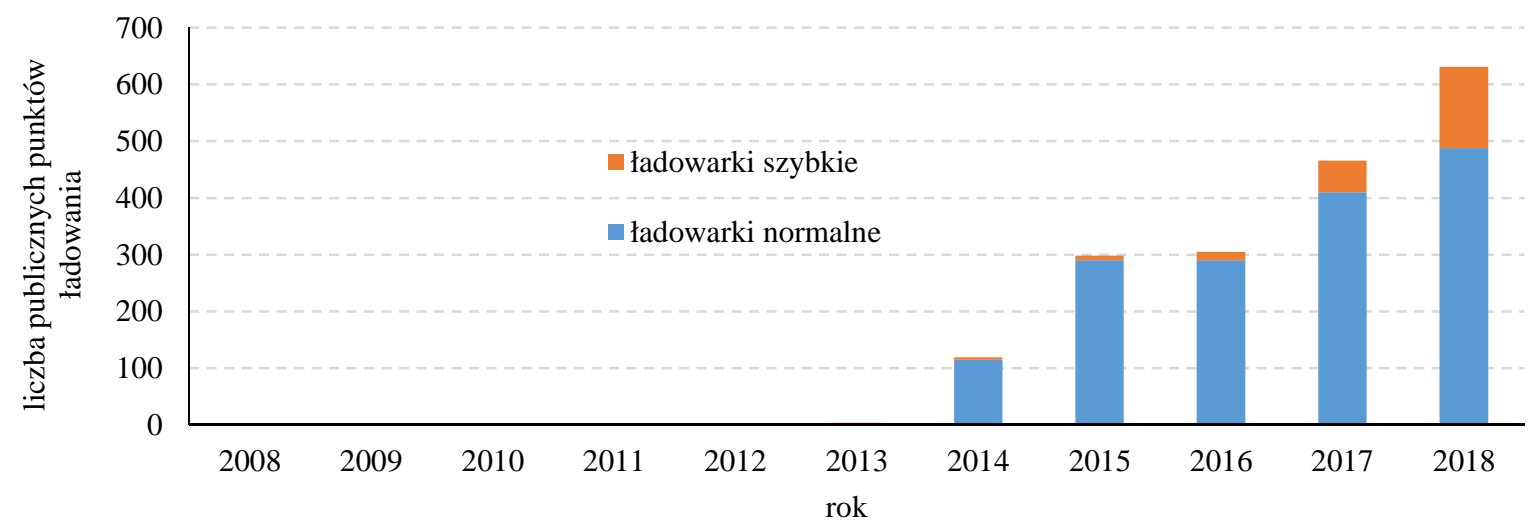

8. Number of public charging points in Poland, 2010-2018 (own study based on [9])

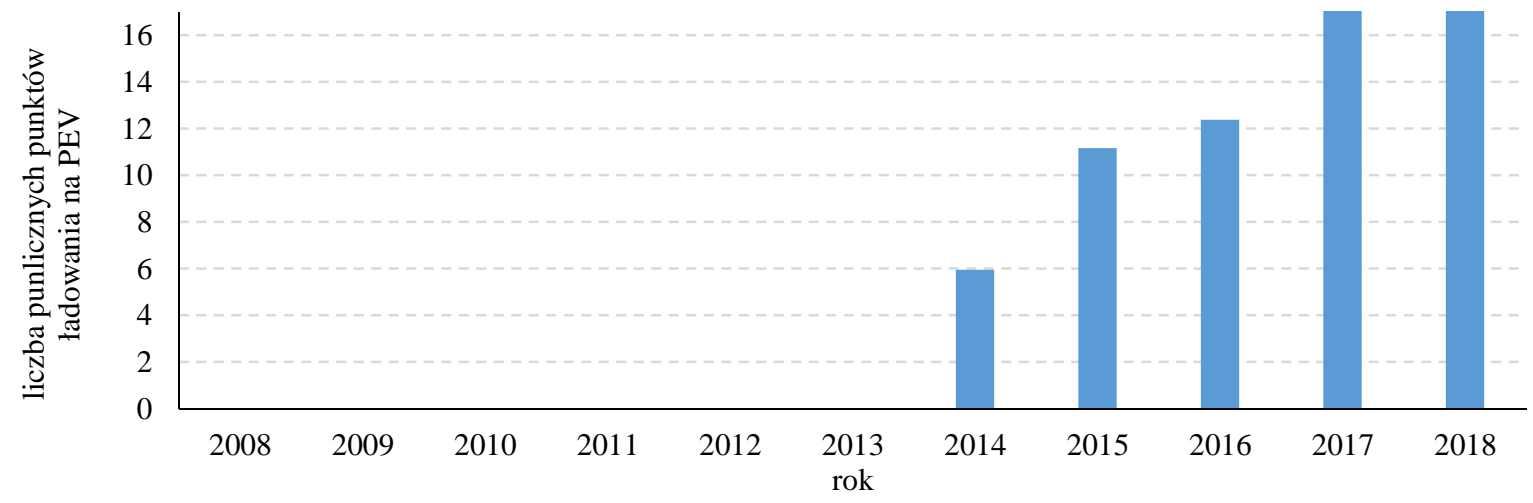

9. Number of PEV per one public charging point in Poland, 2008-2018 (own study based on [9])

However, in the current conditions, when the battery capacity is small, and thus the range of PEV vehicles is small, the location of public charging points is of great importance.

Figures 10 show the location of public charging points in Poland, which shows that they are mostly located in larger cities. This means that with their current location, it is not possible to use such a car for further journeys, e.g. from Warsaw to Gdańsk, without top-up during the journey. Being aware of this, Polish drivers fear that when the battery in their car runs out, they will not be able to recharge it using public chargers and continue their journey. 


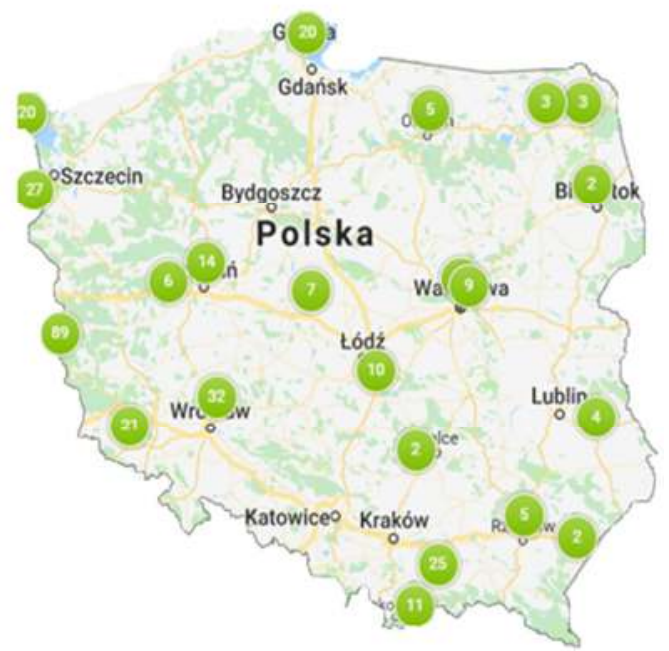

10. Location of charging stations in Poland (as of September 2018) [33]

However, the problem with the placement of charging points is not the only difficulty with the infrastructure of electric cars. Access to it is very often difficult. Many times, in order to be able to use the charging, you must call and make an appointment in advance. It may also turn out that the charging station cannot be used because there is no suitably qualified person who could start the charger. It also happens that the free charging at the car wash can be used only after purchasing the most expensive package [17].

\section{Battery charging time and limited range}

Electric cars, in many respects, have an advantage over cars powered by internal combustion engines, they also have one serious operational disadvantage: limited range. An internal combustion car can travel about $600-800 \mathrm{~km}$ on one fuel tank. Filling the fuel tank and continuing the journey is not a challenge (apart from financial) and after just a few minutes after reaching the gas station, you can go on.

Unfortunately, when traveling by electric car it is currently not realistic. Table $\mathbf{4}$ shows the charging duration, which can range from more than 20 hours to 20 minutes depending on the type of charger and BEV model. The shortest time to charge the battery is with quick chargers, which in 2018 accounted for $23 \%$ of publicly available chargers in Poland (Fig. 8). In addition, table 4 shows the distance that can be traveled by an electric car on a single charge.

It should be remembered that the ranges specified by the manufacturer can be achieved only under optimal conditions - driving at a low and constant speed, gentle acceleration, not using heating and air conditioning and other energy-consuming devices, with a low load of the car (without passengers and luggage), as well as with appropriate ambient temperature. It is difficult to meet all these conditions at the same time, therefore the real range is much lower.

For example, the range of the Tesla $\mathrm{S}$ with batteries up to $100 \mathrm{kWh}$, at an ambient temperature of $-10{ }^{\circ} \mathrm{C}$, heating turned on, a constant speed of $102 \mathrm{~km} / \mathrm{h}$, drops from $800 \mathrm{~km}$ to about $370 \mathrm{~km}$ [18]. The range can be even less if you need to accelerate frequently and the driver needs to do so dynamically, or if you want to go faster. You can try to increase the range by adding more batteries, but this is associated with a significant increase in the price of the car and its weight, which in turn causes even greater energy consumption [20]. 
Tab. 4. Charging time for selected electric cars available in Poland, depending on the type of charger (own study based on [1])

\begin{tabular}{ccccc}
\hline \multirow{2}{*}{$\begin{array}{c}\text { Brand and } \\
\text { model }\end{array}$} & $\begin{array}{c}\text { Total range } \\
(\mathbf{k m})\end{array}$ & $\begin{array}{c}\text { Level 1 } \\
\text { (devices } \\
\text { installed in } \\
\text { private } \\
\text { households) }\end{array}$ & $\begin{array}{c}\text { Level 2 } \\
\text { (slow chargers) }\end{array}$ & $\begin{array}{c}\text { Level 3 } \\
\text { (fast chargers) }\end{array}$ \\
\hline $\mathbf{1}$ & $\mathbf{2}$ & $\mathbf{3}$ & $\mathbf{4}$ & $\mathbf{5}$ \\
\hline $\begin{array}{c}\text { smart fortwo } \\
\text { Electric Drive }\end{array}$ & 109 & 13,6 & 3,4 & 0,32 \\
\hline BMW-i3 & 130 & 16,2 & 4,05 & 0,38 \\
\hline $\begin{array}{c}\text { Volkswagen e- } \\
\text { Golf }\end{array}$ & 134 & 16,6 & 4,15 & 0,39 \\
\hline $\begin{array}{c}\text { Nissan Leaf, 24 } \\
\text { kW-h }\end{array}$ & 135 & 16,8 & 4,2 & 0,4 \\
\hline $\begin{array}{c}\text { Nissan Leaf, 30 } \\
\text { kW-h }\end{array}$ & 172 & 21,4 & 5,35 & 0,5 \\
\hline
\end{tabular}

\section{Conclusions}

According to the research conducted among Poles, the BEV price is undoubtedly the biggest obstacle to the development of electromobility. It is a significant barrier for both private individuals and entrepreneurs. Moreover, when it comes to financial issues, respondents also have serious concerns about the cost of using such cars. A group of consumers even believe that the costs associated with the operation of an electric car are much higher than in the case of vehicles with a conventional drive [25]. Meanwhile, today, from an economic point of view, the total cost of ownership of a TCO electric car is lower than a vehicle with a conventional engine [15].

Therefore, a special role of decision-makers in the development of electromobility in Poland is to make consumers aware of the benefits of using electricity, such as lower operating costs and less harmful to the environment. It is also important for principals to launch, above all, a set of financial incentives in the form of subsidies for the purchase of a vehicle and the expansion of a dense network of public chargers. These non-fiscal ones, i.e. driving bus lanes, free parking in paid places in city parking lots, which have been in force since February 22, 2018, did not contribute to increasing BEV sales in Poland.

According to the report published on October 31, 2017, by the European Automobile Manufacturers Association [16], there is a correlation between the increase in sales of electrically charged cars and the privileges proposed by the principals due to BEV ownership. Therefore, for some time now, there has been a strong trend in Europe to support electromobility in this area. Financial incentives, tax breaks, and exemptions and other incentives are offered to individuals, companies, and local authorities wishing to invest in building public charging points. An example of how much the implemented stimulus can affect the development of EV infrastructure was the tax reduction introduced in 2014 in France for companies that install a charging point in their buildings. The adopted solution brought the intended effects, as already in 2015 an increase in the number of chargers was recorded compared to 2014 by 482\% [35]. Additionally, an extended network of charging points would increase the chances of finding a charger that would be compatible with a given car.

In addition, the legislator has to face one more, quite serious problem that will undoubtedly affect the development of electromobility in the country. Currently, with more 
and more cities in Europe imposing restrictions on the use of diesel cars or even banning them, diesel depreciating in some countries is becoming more attractive in others. Cheap cars that do not meet new air protection standards, considered obsolete in some markets, may become attractive and at the same time problematic for others. Increased imports of used cars with traditional drive may block the natural replacement of the fleet, with all negative effects on the natural environment, delaying or even destroying plans related to the electrification of the transport sector. In the last quarter of 2018, fewer diesel cars were registered for the first time (18\%) than a year ago, i.e. 1.2 million. In this respect, Poland is an exception in Europe. At the same time, i.e. in the last quarter of 2018, 31.8 thous. new cars with a diesel engine, 4.3\% more than last year. Apart from Poland, registrations of new cars with diesel engines increased only in Bulgaria [23].

To sum up, subsidies for purchase, a dense network of public charging points, as well as awareness of using a car that is cheaper to operate and has a less negative impact on the environment should certainly influence the decisions of users when choosing a vehicle with a given type of drive, and thus the development electromobility.

\section{Source materials}

[1] Adderly S. A., Manukian D., Sullivan T. D., Son M. Electric vehicles and natural disaster policy implications. Energy Policy, 2017, 112, , pp. 437-448

[2] Barcik R., Biesok G. Polityka transportowa państw Unii Europejskiej (cz. 1), w: Logistyka, 2004, 2, pp. 10-12

[3] Barisa A., Rosa M., Kisele A. Introducing electric mobility in Latvian municipalities: results of a survey. Energy Proc., 2016, 95, pp. 50-57

[4] Bąk M., Pawłowska B. Koszty zewnętrzne transportu w Unii Europejskiej - od wizji politycznej do jednolitych metod kalkulacji. Przegląd Komunikacyjny, 2008, R. 47, nr $7 / 8$, str. $22-41$

[5] Dziennik Urzędowy Unii Europejskiej nr 307 z dnia 28 października 2014 r. Komisja Europejska

[6] Egbue O., Long S. Barriers to widespread adoption of electric vehicles: an analysis of consumer attitudes and perceptions. Energy Policy, 2012, 48, pp. 717-729

[7] ElectroMobility Poland: Polski Samochód Elektryczny. Czego oczekują kierowcy?, http://www.tnsglobal.pl/coslychac/files/2017/11/AUTA-

ELEKTRYCZNE.pdf\#page=10\&zoom=auto,-214, 515, grudzień 2018

[8] Elektrowóz.pl, www.elektrowoz.pl, grudzień 2018

[9] European Alternative Fuels Observatory, http://www.eafo.eu/, listopad 2018

[10] European Environment Agency. Transport and environment. On the way to a new common transport policy. Office for Official Publications of the EuropeanCommunities: Copenhagen, 2007

[11] Eurostat. Baza danych, http://ec.europa.eu/eurostat/data http://ec.europa.eu/eurostat/data/database, grudzień 2018

[12] Gis M. Populacja samochodów w Polsce, całkowita emisja substancji szkodliwych z silników samochodowych, sposoby ograniczania tej emisji (2). Przegląd Komunikacyjny. 2008, nr 6, s. 20 i 22

[13] Global EV Outlook 2018. Towards cross-modal electrification, https://www.iea.org/tcep/transport/evs/, styczeń 2018

[14] Gradkowski K. Redukcja hałasu od środków lokomocji. Przegląd Komunikacyjny, 2010, nr 7-8, s. 26-31

[15] Haddadian G., Khodayar M., Shahidehpour M. Accelerating the global adoption of electric vehicles: barriers and drivers. The ElectricityJournal, 2015, 28 (10), pp. 53-68 30 
[16] http://www.acea.be/statistics/article/interactive-map-electric-vehicle-incentives-percountry-in-europe, grudzień 2018

[17] http://wysokienapiecie.pl/, listopad 2018

[18] https://www.tesla.com/de_DE/models, grudzień 2018

[19] https://www.volkswagen.pl, grudzień 2018

[20] Igliński H. Instrumenty wsparcia e-mobilności: doświadczenia innych krajów i wnioski dla Polski. E-mobliność:wizje i scenariusze rozwoju, pod redakcją Gajewskiego, J., Paprockiego, W., Pieriegud, J., https://leonardo-energy.pl/wpcontent/uploads/2017/07/E-mobilnosc_wizje_i_scenariusze_rozwoju.pdf, styczeń 2018

[21] Innogy:Autostrada do elektromobilności. Czy jesteśmy gotowi na samochody elektryczne?, $\quad$ https://www.innogy.pl/pl/ /media/Innogy-

Group/Innogy/Polska/Dokumenty/Artykuly/2017/innogy-polska-raport-autostrada-doelektromobilnosci-web.pdf, styczeń 2018

[22] Kamińska T. Koszty i korzyści zewnętrzne transportu (1). Przegląd Komunikacyjny, 1998, nr 7, s. 13

[23] Komisja Europejska: Biała Księga - Plan utworzenia jednolitego europejskiego obszaru transportu - dążenie do osiągnięcia konkurencyjnego i zasobooszczędnego systemu transportu. KOM(2011) 144 wersja ostateczna, Bruksela 2011

[24] Komputerowy System INFO-EKSPERT - wycena samochodów, grudzień 2018

[25] Krause R., M., Carley S., R. Lane B., W., Graham J., D. Perception and reality: public knowledge of plug-in electric vehicles in 21 U.S. cities. Energy Policy, 2013, 63, pp. 433-440

[26] Lam A., Leung Y., S., Y-W., Chu X. Electric Vehicle Charging Station Placement: Formulation, Complexity, and Solutions. IEEE Transactions on Smart Grid, 2014, Volume 5, Issue 6, pp. 2846 - 2856

[27] Mazur E. Terenochłonność transportu w niektórych krajach. Przegląd Komunikacyjny, 1993, nr 5, s. 14-15

[28] Menes M. Światowy rynek ropy naftowej: stan i perspektywy. Przegląd Komunikacyjny, 2006, nr 7/8, s. 51-55

[29] Menes M. Światowy rynek ropy naftowej na progu drugiej dekady XXI wieku. Przegląd Komunikacyjny, 2013, 9, s. 6-10

[30] Ministerstwo Energii, https://www.gov.pl/web/energia/, styczeń 2018

[31] Ministerstwo Energii: Krajowe ramy polityki rozwoju infrastruktury paliw alternatywnych, http://bip.me.gov.pl/node/26450, grudzień 2018

[32] Navigant Research: Analizy EY, www.navigantresearch.com, styczeń 2018

[33] Nissan. Innovationthatexcites: Płynna podróż na wyciągnięcie ręki. Łatwe wyszukiwanie punktów ładowania, https://www.nissan.pl/pojazdy/nowepojazdy/leaf/zasieg-ladowania.html\#EVINFRASTRUCTURE, listopad 2018

[34] Polski Związek Przemysłu Motoryzacyjnego, http://www.pzpm.org.pl/, listopad 2018

[35] Sendek-Matysiak, E. Ocena stanu infrastruktury transportu drogowego w Polsce w latach 2000-2015 przez kierowców. Prace Naukowe Politechniki Warszawskiej, 2017, z. 117, s. 331-341

[36] Skala-Poźniak A. Aktualne kierunki polityki transportowej UE. Przegląd Komunikacyjny, 2002, nr 5, s. 6.

[37] Sovacool B., K., Hirsh R., F. Beyond batteries: an examination of the benefits and barriers to plug-in hybrid electric vehicles (PHEVs) and a vehicle-to-grid (V2G) transition. Energy Policy, 2009, 37, pp. 1095-1103

[38] The State of the Environment in the European Community, COM (23) final, vol. III, p. 71, Brussels 1992 
[39] Węglarz A., Pleśniak M. Z energetyką przyjazną środowisku za pan brat. Samochód elektryczny. Fundacja Instytut na rzecz Ekorozwoju, Warszawa 2011

[40] www.elektromobilini.pl, listopad 2018

[41] Zhang Y., Yu Y., Zou B. Analyzing public awareness and acceptance of alternative fuel vehicles in China: the case of EV. Energy Policy, 2011, 39, pp. 7015-7024 